\title{
Et visst
}

\section{talent for}

\section{å overleve}

\author{
- Jeg er ikke et menneske hvis identitet ligger i at jeg har utlagt tarm. Professor i europeisk \\ kunsthistorie Gunnar Danbolt er kjent for sine kunstreiser på P2 - hans formidlingsevner \\ gjorde ham i 2007 til ridder av første klasse av St. Olavs Orden. At Danbolt tilbrakte år av sin \\ ungdom på sykehus med livstruende tilstander, dels frembrakt av selvhenførte leger, har \\ aldri vært noe stort poeng for ham. Det er nettopp poenget. Han lærte det av sin mor. \\ Tidsskriftet møtte professoren til en førjulssamtale om kunsten å leve - og overleve.
}

Gjennom glassveggen på Stenersensamlingen i Bergen sentrum ser vi fuktig bypark, hastige mennesker, måker i bedagelig kretsing over Lille Lungegårdsvann. Kinesisk installasjonskunst fyller rommene - tusener av rustne sigder og hammere i tykke lag på gulvet, forvokste plastkropper med omsorgssvikt i tomme blikk, et gyllent skjelett i løse deler. Gunnar Danbolt siger godt ned i en svart skinnsofa. Han er egentlig på reisefot, til Roma selvfølgelig, for å fortelle, skape indre bilder.

Han ser på meg med milde øyne i et ansikt mykt innrammet av hvitt hår og skjegg. Mannen synes å inkarnere alle dannelsens fasetter: Hans muntert gammelmodige finbergensk holder seg til rettskrivningen av 1917. Fagkretsen er gammelgresk, latin og kunsthistorie. Han tenker kritisk, han skriver bøker, han griper inn i tiden med begeistring. Han er interessert og åpen som radiostemme og samtalepartner - han er den dannede som får andre til å føle seg vel.

I Danbolts egen dannelseshistorie har norsk helsevesen hatt stor betydning, blant annet ved å redde livet hans. Men smilet blir en anelse syrlig når han forteller om de mer bisarre tiltak han er blitt utsatt for. Den unødvendige nakkeoperasjonen som kostet ham tre måneder i strengt ryggleie $\mathrm{i}$ et dårlig tilpasset gipsskall før han var 20 år. Professoren som ville bruke ham til kirurgisk prøvekanin uten å spørre. To velmente kneoperasjoner hvor feilstillingen i føttene ble større, ikke mindre. Barnelegene som sa at han ikke burde gå på skole, han var jo så forferdelig syk ... var nær venn av far. Hver gang han hadde vært på kongress, kom han hjem med en ny behandling. En gang var det en banankur, jeg spiste bare bananer i tre måneder, det hjalp heller ikke. Problemet var at avføringene økte og økte, til slutt var det mellom 20 og 30 daglig, og min funksjonsdyktighet var ganske liten. Det var da det viktige skjedde. Min mor sa: «Egentlig er du ikke syk i vanlig forstand, det er bare visse ting som ikke fun-

\section{«Legene kan gjøre feil, men det er dem man må holde seg til»}

gerer med deg, slik det også var da du ble født. Da ordnet vi det ved at du hadde en bleie, og det kan vi faktisk også bruke nu.»

Plasten var ikke god den gang, men mor fikk sydd en hel del underbukser til meg som satt nokså tett, med strikk. På den måten kunne jeg faktisk gå på skolen. Barnelegen sa at det ikke var tale om, jeg kunne ikke gå ute blant folk i det hele tatt. Men ved hjelp av den lille oppfinnelsen og det at min mor sa jeg egentlig var frisk, så gikk jeg på skolen. Jeg tok realskole og gymnas. Jeg var mye på sykehus. Men jeg betraktet aldri meg selv som syk. Mine to nærmeste venner visste nok om det, men ellers tror jeg ikke de andre la merke til noe spesielt. Jeg måtte i hvert friminutt gå på do og skifte. Det var litt utfordrende med de gamle bleiene, men jeg fikset det. Slik var det på konserter og i teateret også, jeg måtte alltid skifte i pausen.
- Ingen plagsomme lyder?

- Nei, ikke mye. Men plasten kunne sprekke slik at det kom litt lukt. Men de laget stadig nye bukser, så jeg klarte meg ganske bra. Og jeg vet ikke hvordan det skulle gått om vi ikke hadde gjort dette, om jeg var blitt liggende. En pike jeg kjente, fikk det omtrent samtidig, hun døde efter noen år. Det var det vanlige. Hvis de fikk det $\mathrm{i}$ så høy grad som jeg hadde det.

\section{Psykisk?}

- De trodde jo på den tiden at det var psykisk. Jeg var født like før krigen, og de mente det kunne være traumer derfra. Så jeg hadde da i 1952 en rekke psykiatere som snakket med meg om alle mulige ting. De fant ikke at jeg var noe særlig rammet. Men de lærte meg å slappe av, og det var ganske viktig. Jeg lærte å tenke «venstre hånd er tung som bly, høyre hånd er tung som bly, høyre fot ...» og så videre. Det brukte jeg senere når jeg hadde store smerter, det hjalp. Ellers fikk jeg av psykiaterne vite alle mulige ting om seksualitet og slikt som jeg simpelthen ikke forsto! Danbolt ler.

- Jeg var 12 år, kom hjem og fortalte min ett år yngre bror om seksuallivet. Han holdt på å le seg i hjel, for jeg hadde misforstått alt sammen. Jeg var jo ikke akkurat kjønnsmoden på den tiden, vet du.

\section{Dømt til å være normal}

- Jeg blir interessert i foreldrene dine ...

- Ja, jeg var svært heldig med dem. De snakket aldri om meg som syk, de behandlet meg aldri som syk, og jeg så ikke på meg selv som syk. Det var liksom ingen unnskyldning at jeg akkurat hadde dette her. Og jeg er veldig takknemlig for det. Jeg har tenkt på at om jeg hadde hatt mine svigerfor- 


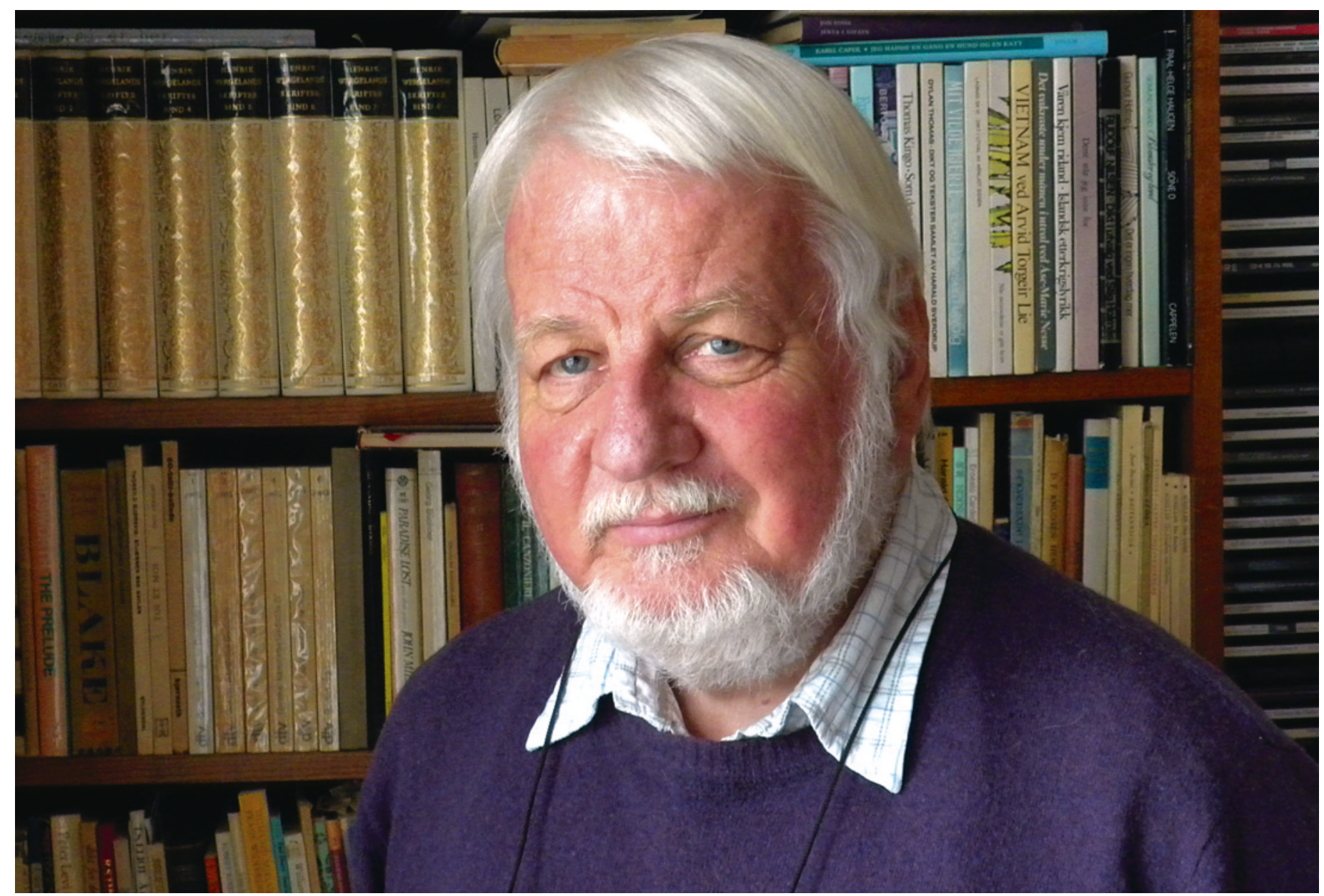

Foto privat

\section{Gunnar Danbolt}

\section{Født 9.3. 1940 i Bergen}

- Studier i latin, gresk og kunsthistorie i 1960-årene

- Mag.art. i 1971 på avhandlingen Pozzoen i San Bartolomeo all'Isola i Roma. Romersk skulptur på 1000-tallet. Har siden utgitt en rekke fagbøker, sist Jeg former, altså er jeg: om Zdenka Rusovas billedunivers (2007)

- Professor i kunsthistorie ved Universitetet i Bergen fra 1984

- Meltzerfondets pris for fremragende forskningsformidling i 1999

- Ridder av 1. klasse av St. Olavs Orden, for fremragende forskningsformidling. i 2007 eldre som foreldre, så hadde jeg simpelthen ikke levd. De hadde vært helt fra seg. - Som lege finner jeg det krevende å takle foreldres velmente risikokretsing, bekymring og stakkarsliggjøring av syke barn. Det er forståelig, men skadelig. Dine foreldre var jo noen råskinn som ikke ga deg en eneste sekundærgevinst av problemene dine. Slik dømte de deg til å være normal. Det er flott å tenke på, jeg blir rørt.

- Jeg er takknemlig for at begge mine foreldre var så rolige. Professor Sundal advarte sterkt mot at jeg skulle begynne på realskolen. Men da sa far: «Hvis gutten selv vil, så må han få lov til det.» Og det gikk fint. Men da det nærmet seg artium, var jeg på Rikshospitalet, legene fant ut at kolitten nærmet seg tynntarmen. De rådet meg fra å ta artium, de mente det ville være for stor påkjenning. Men jeg bestemte meg for å gjøre det, jeg visste at jeg ikke skulle ta et studium hvor jeg trengte beste karakter.

Og det har jeg ikke angret på. Selv om jeg ble veldig dårlig like efterpå. Så dårlig at den store professor Gade i Bergen måtte legge ut tarmen min. I 1958 var det ikke så vanlig med utlagt tarm for ulcerøs kolitt.
Han fjernet hele tykktarmen gjennom et lite snitt her på høyre side, uten å skjære meg opp tvers over magen, for at jeg ikke skulle bli så ødelagt. De som var med på den operasjonen, sa det var et kunstverk, at han var helt utrolig dyktig. Det var en veldig vond operasjon, men det gikk nå greit.

Stemmeklangen mister sin mykhet. Jeg spør: - Hva mener du med vond?

- Jeg hadde enorme smerter efterpå. Det var blod i buken og så videre. Men det gikk nå over. Tonen er forretningsmessig og signaliserer at det ikke er mer å snakke om.

- Jeg har et forholdsvis - avslappet - forhold til smerter.

Det blir en liten pause i samtalen. Vi ser ut gjennom glassveggen - våt, grønn park.

\section{Latter og greske tragedier}

- Men så, samme høst, var det at Gade også tok denne operasjonen i nakken. Han trodde jo han kunne alt. Noen av de uvirksomme medikamentene for kolitt hadde skadet nakkevirvlene. Jeg lå der i tre måneder i et gipsskall som ikke passet til kroppen min. Jeg fikk liggesår i hodet og ble lam i armene. Så ble jeg en dag kjørt inn på et av disse 
rommene på Haukeland hvor jeg visste at man ikke kom ut levende. Jeg var godt kjent. Jeg husker at assistentlege Ofstad og professor Broch, mine leger, de sto og gråt ved sengen min.

Da hadde jeg en underlig drøm en natt. Jeg var med min tante på en premiere på Den Nationale Scene, slik jeg ofte hadde vært. I drømmen sa hun: «Husk, det er teater på onsdag.» Plutselig var onsdag bare noe svart, jeg forsto at det ikke var noen onsdag. Jeg ble fryktelig redd. En sykepleier kom, hun bare satt der og holdt meg $\mathrm{i}$ hånden. Om morgenen tenkte jeg: Nei, jeg kommer ikke til å dø.

Jeg ba min mor ta med noen Wodehousebøker til meg (P.G. Wodehouse: engelsk forfatter kjent for humoristiske bøker fra overklassemiljø). Hun sa: «Men Gunnar, du vet jo at du er alvorlig stedt, du skulle kanskje ta Det nye testamente i stedet?» «Nei,» sa jeg, «jeg vil gjerne ha Wodehouse.» Og så hadde jeg Wodehouse og lo noe enormt. Kjenner du P.G. Wodehouse, i Axel Seebergs oversettelse?

Jeg humrer, Wodehouse-bøkene var blant favorittene i min fars bokhyller.

- Jeg lo virkelig, virkelig mye. Og efter noen uker ble jeg kjørt inn igjen på den store salen med 24 senger. Det hadde de ikke trodd. Så fant de ut at jeg hadde fătt tuberkulose i nakkevirvlene, jeg var smittet på sykehuset. Det reddet meg på en måte. Lungelegen sa: «Du må ligge et år i strekk med et ti kilos lodd fra hodet.»

Det var jo en forferdelig sak å få vite at man hadde tuberkulose i 1959, sykdommen hadde mye av disse fordommene som kreft har i dag. Og så måtte jeg flytte til Lungeavdelingen, et helt ukjent sted. Du vet når man ligger lenge på sykehus, blir dette med å skifte sted en stor påkjenning. Men alle var veldig hyggelige, jeg fikk et hjørnerom med utsikt. Oversøster på kirurgen kom til meg med noen prismebriller slik at jeg kunne lese selv om jeg lå i strekk. Lenge hadde jeg et stativ som holdt boken, de hjalp meg å bla om. Og efterhvert fikk jeg førligheten tilbake, kunne løfte bøkene selv. Men jeg var jo ganske nedfor, da. Å skulle ligge et år i strekk, jeg var 19 ...

Så gjorde jeg det jeg ofte hadde gjort før - jeg leste en gresk tragedie. Og gjennom det fikk jeg på en måte ut min fortvilelse, fikk overvunnet den. Det var en strategi jeg hadde lært meg til som var ganske grei. Mine foreldre kunne ikke forstå at jeg ikke gråt mer, var mer fortvilet. Jeg gjorde jo det, men jeg gjorde det i stillhet. Jeg fikk alt sammen ut ved å lese høyt fra tragediene, leve meg inn i karakterene.

\section{Sykdomsfokus er ytterst uheldig}

- Jeg har vel hatt et visst talent for å være «pasient» - i betydningen tålmodig. Jeg vente meg til alt sammen og fikk lest veldig mye. Så det året var i grunnen ganske fruktbart. Det er ikke noe jeg bare sier efterpå,

\section{«Livskunst handler om à takle de utfordringer livet gir en»}

jeg opplevet det slik mens det sto på. Jeg fikk orden på tarmen, med poser og slikt. Så måtte jeg gå med nakkestøtte i to år. Den var ikke akkurat så flott, folk snudde seg hele tiden. Jeg studerte latin i to år, så gresk. Interessen var blitt sterkere mens jeg lå og leste, jeg måtte vite mer om den litteraturen.

Utover i 1960- og 70-årene gikk det godt for den unge akademikeren, men kroppen var brysom. Han måtte opereres enda en gang i nakken og fikk vite at den første operasjonen hadde vært mislykket, de hadde avstivet feil nivå. Nye tre måneder i gipsskall. Han ble operert for flere nyresteiner, fikk fjernet endetarmsresten, fikk operert knærne - uten suksess - og har i nyere tid fått proteser i begge knær - med godt resultat.

- Du har hatt mye tillit til leger, nærmest mot bedre vitende?

- Ja, du kan si det. Jeg skjønte tidlig at jeg måtte stole på legene. Min far sa alltid at legene kan gjøre feil, men det er dem man må holde seg til. Man ville i 1970-årene gjerne ha meg med i en pasientforening for dette med utlagt tarm. Det var jeg overhodet ikke interessert i. Jeg er jo ikke et menneske hvis identitet ligger $i$ at jeg har utlagt tarm.
Jeg tror det er yderst uheldig at man har fokus på sykdommen hele tiden. Jeg treffer mennesker med kreft som er så uendelig opptatt av at de har den kreften. Jeg forstår det godt, men tror ikke det gavner dem at de har oppmerksomheten låst til sine problemer. For meg har det ikke vært slik, derfor har jeg hatt et godt liv.

\section{Fri vilje er å kunne skifte spor}

- Man må kunne se i andre retninger. Om den frie vilje sa de greske kirkefedrene at viljen $i$ og for seg er bundet - men man har alltid mulighet for å skifte spor. Hvis man er veldig sulten og står utenfor en bakerforretning og bare blir stående der og glo, så er muligheten for at man stjeler overhengende.

Men mennesket har alltid muligheten til å bli opptatt av noe annet hvor dette ikke lenger blir så viktig. Det var det de mente med den frie vilje, at mennesket har muligheten for å transcendere, overskride sin egen situasjon.

\section{Livskunst}

- Hva innebærer «kunst» i ordet livskunst?

- Ordet kunst kommer av å kunne, og livskunst handler om å takle de utfordringer livet gir en. Det er noe som i og for seg ikke er gitt, men som man kanskje må trene seg opp til. Som med «legekunst» - det handler om fortrolighets- og ferdighetskunnskap, viten som ikke lar seg artikulere fullt ut, men som ikke desto mindre er kunnskap og helt avgjørende for å klare seg.

Fortrolighetskunnskap er å vite eller kunne noe uten å kunne redegjøre for hvordan, som å forstå språk eller kjenne igjen ansikter, stemmer, lukter, hjertelyder, følelser. Mens lærebøkenes påstandskunnskaper er noe man har, blir fortrolighetskunnskap og kroppslige ferdigheter noe man er. Man blir litt efter litt forandret og kan ikke tenke seg hvordan det er å være uten disse kunnskapene. Derfor kan man ikke bare lese bøker og bli lege - eller et klokt menneske. Man må leve, man må kanskje lide, og man må være heldig med dem man møter på veien.

\section{Edvin Schei}

edvin.schei@isf.uib.no

Tidsskriftet 